ARTICLE

DOI: $10.1038 / s 41467-018-06892-w$

\title{
Nutrient supply controls particulate elemental concentrations and ratios in the low latitude eastern Indian Ocean
}

\author{
Catherine A. Garcia (10 1, Steven E. Baer (10) 2,4, Nathan S. Garcia1, Sara Rauschenberg², Benjamin S. Twining (D) 2, \\ Michael W. Lomas ${ }^{2}$ \& Adam C. Martiny (1) 1,3
}

\begin{abstract}
Variation in ocean C:N:P of particulate organic matter (POM) has led to competing hypotheses for the underlying drivers. Each hypothesis predicts $C: N: P$ equally well due to regional co-variance in environmental conditions and biodiversity. The Indian Ocean offers a unique positive temperature and nutrient supply relationship to test these hypotheses. Here we show how elemental concentrations and ratios vary over daily and regional scales. POM concentrations were lowest in the southern gyre, elevated across the equator, and peaked in the Bay of Bengal. Elemental ratios were highest in the gyre, but approached Redfield proportions northwards. As Prochlorococcus dominated the phytoplankton community, biodiversity changes could not explain the elemental variation. Instead, our data supports the nutrient supply hypothesis. Finally, gyre dissolved iron concentrations suggest extensive iron stress, leading to depressed ratios compared to other gyres. We propose a model whereby differences in iron supply and $\mathrm{N}_{2}$-fixation influence C:N:P levels across ocean gyres.
\end{abstract}

\footnotetext{
${ }^{1}$ Department of Earth System Science, University of California at Irvine, Irvine, CA 92617, USA. ${ }^{2}$ Bigelow Laboratory for Ocean Sciences, East Boothbay, ME 04544, USA. ${ }^{3}$ Department of Ecology and Evolution, University of California at Irvine, Irvine, CA 92617, USA. ${ }^{4}$ Present address: Maine Maritime Academy, Castine, ME 04420, USA. Correspondence and requests for materials should be addressed to A.C.M. (email: amartiny@uci.edu)
} 
lemental ratios of particulate organic matter (POM) are key to linking biogeochemical cycles. The carbon:nitrogen: phosphorus (C:N:P) ratio is often assumed globally constant at Redfield proportions (106C:16N:1P). However, recent observations show high ratios in nutrient-poor subtropical gyres and low ratios in nutrient-rich environments ${ }^{1,2}$. There are also ocean basin differences with higher C:P and N:P values in the North Atlantic subtropical gyre and lower ratios in other subtropical gyres $^{3,4}$. However, many regions remain woefully under-sampled, especially in regards to particulate organic phosphorus (POP).

Individual studies have presented competing hypotheses explaining global variation in the elemental ratios of $\mathrm{POM}^{5}$. First, the translation-compensation hypothesis predicts a negative relationship between temperature and the cellular concentration of P-rich ribosomes as higher temperatures increase ribosomal translation efficiency ${ }^{6}$. This would lead to a positive relationship between temperature and $\mathrm{C}(\mathrm{N}): \mathrm{P}$ ratios. Second, the nutrient supply hypothesis predicts that nutrient stressed cells are frugal and have low cell quotas of the limiting nutrient. For example, this hypothesis predicts a negative correlation between C:P and ambient $\mathrm{P}$ availability 7,8 . Thirdly, the allometric diversity hypothesis predicts that smaller, nutrient uptake specialists like Prochlorococcus have elevated C:P and $\mathrm{N}: \mathrm{P}$ in comparison to larger lineages like diatoms ${ }^{1,8,9}$. However, it is a challenge to separate these hypotheses as temperature, nutrient supply, and community composition strongly co-vary in the ocean.

The Indian Ocean (IO) accounts for 15-20\% of global ocean net primary production ${ }^{10}$, but there are few published data that describe the ocean biogeochemistry of POM in this region. In the Indian Ocean spring inter-monsoon season, sea surface temperatures (SST) and macronutrient concentrations increase northwards. Strong gradients in temperature and nutrient concentrations in the surface ocean suggest three distinct regions: an oligotrophic, cooler $\left(20.5-29.7^{\circ} \mathrm{C}\right)$ Southern Indian Ocean gyre (SIO gyre); a warm $\left(30.3-31.5^{\circ} \mathrm{C}\right)$ upwelling region north of $10^{\circ} \mathrm{S}$ (EqIO); and a warm $\left(29.1-32.6^{\circ} \mathrm{C}\right)$, higher biomass region in the Bay of Bengal $(\mathrm{BoB})^{11}$. Although surface nutrient concentrations are consumed to near depletion throughout the basin, two overturning thermohaline cells deliver nutrient-replete water close to the surface around $10^{\circ} \mathrm{S}$ and slightly north of the equator $^{12}$. However, the northern branch of the cross-equatorial cell is not well defined ${ }^{13}$. The BoB also has elevated nutrient supply driven seasonally by coastal upwelling and river inputs, thereby leading to periods of increased productivity ${ }^{14}$. Thus, it appears that the warmest regions are also the most nutrient replete in the eastern Indian Ocean leading to temperature and macronutrient supply being uniquely positively correlated. As such, this region enables a test of our hypotheses for how phytoplankton stoichiometry ratios are controlled.

Here, we ask the following three questions about environmental and biological controls of biogeochemistry in the eastern Indian Ocean: How do POM concentrations and elemental ratios vary between regions and on short-term scales within regions? How do the phytoplankton community composition and environmental conditions relate to variation in POM concentrations and elemental ratios? Is the SIO gyre unique in terms of its POM concentrations, ratios, and controls compared to other oligotrophic gyres?

Our results suggest that nutrient supply is the leading driver of regional variation in elemental composition in the eastern Indian Ocean as well as other low latitude regions. However, the C:P ratio in the SIO gyre is low in comparison to other subtropical gyres leading us to propose that iron stress controls the POM C:P ratio in oligotrophic regions via regulation of $\mathrm{N}_{2}$-fixation. Thus, the unique biogeochemistry of the Indian Ocean provides key information for understanding the controls of ocean C:N:P.

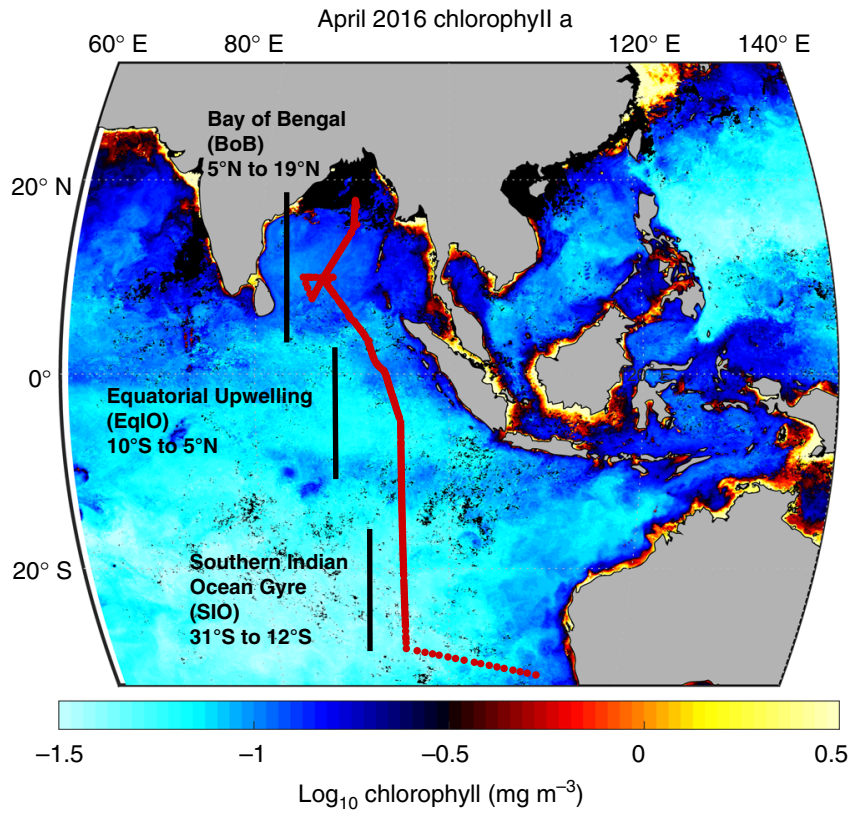

Fig. 1 Study region. The transect sampling locations for GO-SHIP cruise IO9N are marked by the red dots. The approximate latitudinal range of proposed regions is marked by black bars. Chlorophyll concentrations are from MODIS-Aqua 4 km April 2016 monthly average ${ }^{17}$. Figure was created in MATLAB using fireice.m colormap package

\section{Results}

I09N transect environmental gradients. To quantify the link between environmental gradients, phytoplankton community composition, POM concentrations, and ratios, we collected samples across 238 stations in the eastern Indian Ocean (Fig. 1, Supplementary Data 1). Both the western and eastern Indian Ocean experienced anomalously warm SST during the sampling period. However, there was an overall positive Indian Ocean Dipole (IOP +0.34, April 2016) since the eastern basin was cooler. These conditions favor wind patterns that promote upwelling off Indonesia ${ }^{15}$. Based on near surface temperature and nutrient concentration gradients, we classified the transect into the SIO gyre $\left(31^{\circ} \mathrm{S}-12^{\circ} \mathrm{S}\right)$, an equatorial upwelling region (EqIO, $\left.10^{\circ} \mathrm{S}-5^{\circ} \mathrm{N}\right)$, and the $\mathrm{BoB}\left(5^{\circ} \mathrm{N}-19^{\circ} \mathrm{N}\right)$ (Fig. 2a, b and Supplementary Fig. 1). Due to uncertainty in the SIO gyre-Indonesian through flow transition, $12^{\circ} \mathrm{S}$ was used instead of $10^{\circ} \mathrm{S}$ as the gyre northern cutoff. We used the depth of the $1 \mu \mathrm{M} \mathrm{NO}$ isocline to define the nutricline and applied this as a proxy for nutrient supply into the surface layer (Fig. 2b, Supplementary Fig. 2) ${ }^{16}$. SIO gyre had the lowest surface temperature and the deepest nutricline depth along the transect $(129 \mathrm{~m})$ (Supplementary Table 1 and Fig. 2a, b). EqIO was characterized by temperatures above $29^{\circ} \mathrm{C}$ and the nutricline shoaled to $62 \mathrm{~m}$. Increased nitrate concentrations below the nutricline near $10^{\circ} \mathrm{S}$, the equator, and $5^{\circ}$ $\mathrm{N}$ corresponded to bands of elevated chlorophyll (Fig. 1) ${ }^{17}$. This suggests high nutrient supply at these bands. In BoB, temperature was on average $30.8^{\circ} \mathrm{C}$, and the nutricline remained constant $(61 \mathrm{~m})$. Overall, there was a coupled negative relationship between SST and nutricline depth $(R=-0.88)$. Thus, there were significant regional environmental differences, but in support of our prediction, a uniquely positive relationship between temperature and the nutrient supply.

Short term and regional variation in POM. We identified significant diel variability of POM concentrations and elemental 


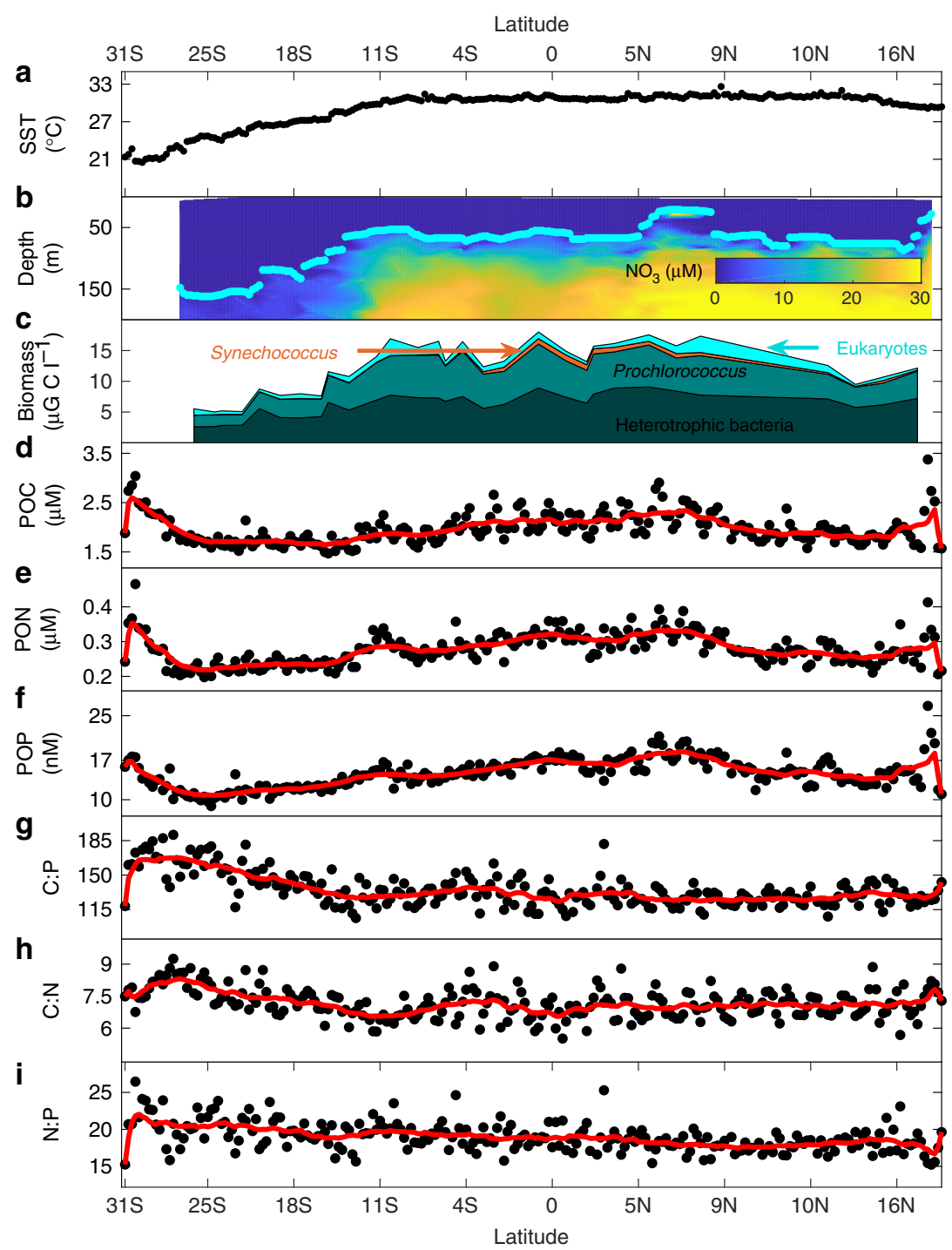

Fig. 2 Observations of environmental conditions, relative phytoplankton biomass, POM concentrations, and ratios across the eastern tropical Indian Ocean. a Sea surface temperatures; b nitrate concentrations as shaded background and nutricline depth (depth with $1 \mu \mathrm{M}\left[\mathrm{NO}_{3}\right]$ ) marked by light blue dots; c Phytoplankton absolute biomass; d particulate organic carbon (POC); e particulate organic nitrogen (PON); $\mathbf{f}$ particulate organic phosphorus (POP); g POC:POP (C:P); h POC:PON (C:N); and $\mathbf{i} P O N: P O P(N: P)$. In panels $\mathbf{d}-\mathbf{i}$, averages of analytical triplicates are marked by black dots, the red line represents an 8-sample moving average, and elemental ratios are molar. First and last 4 end points are averaged over fewer than 8 points. For bacteria and phytoplankton: Bact(dark green) $=$ Heterotrophic bacteria, Pro(greenblue) $=$ Prochlorococcus, Syn(orange) $=$ Synechococcus, and Euks $($ cyan $)=$ Eukaryotes

ratios (Fig. 3). Particulate organic carbon (POC) had the strongest cycle with a maximum at dusk, and minimum at dawn. POP had a similar cycle, whereas particulate organic nitrogen (PON) cycled with a peak between midnight and 07:00 local time (Supplementary Table 1). The stronger oscillation in POC led to C:N and C:P maxima near dusk. The temporal shift in the peak of PON relative to POP led to a weak $\mathrm{N}: \mathrm{P}$ ratio maximum at 17:00 local time. Over the course of a day, on average the ratio of C:P changed by $13.4, \mathrm{~N}: \mathrm{P}$ by 0.64 , and $\mathrm{C}: \mathrm{N}$ by 0.58 in the eastern Indian Ocean. These daily ranges were comparable to differences observed between regions (Supplementary Table 1).

We next found distinct diel amplitudes across regions (Fig. 3). The smallest amplitudes for all POM concentrations and elemental ratios were observed in SIO gyre, but no significant differences between the $\mathrm{BoB}$ or EqIO regions (Supplementary Table 1). Using the daily POC range as a proxy for daily biomass accumulation, the highest normalized accumulation rates were observed on the coastal margin of Western Australia at $30.7^{\circ} \mathrm{S}$,
EqIO at $2.4^{\circ} \mathrm{S}$, and intermittently northwards at $5^{\circ} \mathrm{N}, 8.5^{\circ} \mathrm{N}$, and $17.2^{\circ} \mathrm{N}$ (Supplementary Fig. 3). In contrast, the POC normalized accumulation rates were dampened in SIO gyre. The nutrient and hydrography profiles suggested upwelling at $\sim 4-8^{\circ} \mathrm{N}$, where two of the POC normalized accumulation peaks were observed (Supplementary Fig. 1). Thus, there appeared to be increased daily carbon accumulation in regions with elevated nutrient availability.

We found significant regional variation in the concentration and ratios of POC, PON, and POP (Fig. 4 and Supplementary Table 2). POM concentrations were lowest in SIO gyre and higher northwards (Supplementary Table 1). In BoB, the POM concentrations decreased from $9^{\circ} \mathrm{N}$ to $15^{\circ} \mathrm{N}$ followed by a sharp increase in waters overlying the continental shelf (Fig. 2d-f). Although the nutricline shoals, nutrients may be entrained below the thermocline due to strong salinity gradients in BoB leading to low POM concentrations ${ }^{18}$. The elemental ratios followed similar declining northward trends, with high ratios in the SIO gyre and 


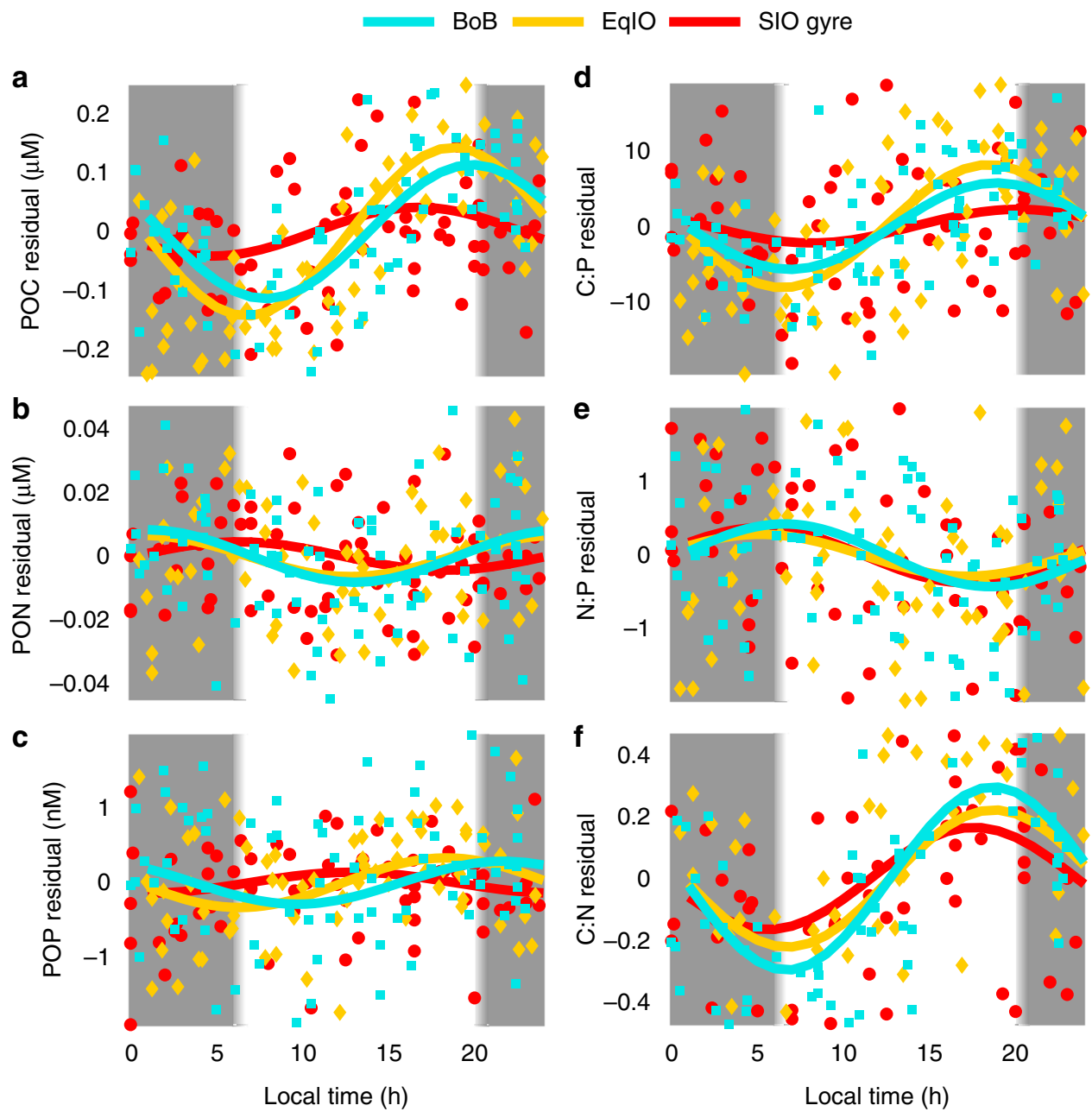

Fig. 3 Diel variation in POM concentrations and ratios. Residuals are calculated as follows: data points subtracted from the 8-point smoothed line for a particulate organic carbon (POC), b particulate organic nitrogen (PON), c particulate organic phosphorus (POP), d POC:POP (C:P), e PON:POP (N:P), and $\mathbf{f} P O C: P O N(C: N)$. Points were plotted and a sine curve was fitted for each region. Bay of Bengal $(B o B)$ is in cyan. Equatorial Upwelling (EqIO) is in gold. Southern Indian Ocean gyre (SIO gyre) is in red. The grey bar represents local nighttime and white bar represents daytime

low ratios in the north. C:P and C:N decreased sharply during the transition from SIO Gyre (C:P 150, C:N 7.6) to EqIO (C:P 131, C: $\mathrm{N} 7.0$ ), but stayed slightly above Redfield proportions in the EqIO and the BoB (C:P 127, C:N 7.1) (Fig. 2g-i). N:P decreased gradually northward throughout the transect (N:P: SIO gyre $=$ $20.1 \mathrm{EqIO}=19.0, \mathrm{BoB}=17.9)$. Thus, there were clear regional differences in elemental ratios across the eastern Indian Ocean.

Testing ecological stoichiometry hypotheses. We next tested the three proposed stoichiometry models for POM stoichiometry trends in the Indian Ocean. First, we addressed the allometric diversity hypothesis. Consistent with past studies ${ }^{19}$, Prochlorococcus dominated the phytoplankton portion with only small contributions from picoeukaryotic phytoplankton and Synechococcus. The picoeukaryotic phytoplankton increased in biomass north and south of the equator, while the Synechococcus biomass increase centered on the equator. Residual effects of coastal upwelling could explain the increases in Synechococcus in the EqIO ${ }^{15}$, but the overall Synechococcus contribution to phytoplankton composition was small. Larger phytoplankton were rare and the ratio of photo-to-heterotrophic plankton biomass was nearly 1:1 throughout the transect. A linear regression model showed no significant explanatory power of relative biomass composition for POM concentrations and elemental ratios
(Supplementary Table 3, Supplementary Fig. 4). Instead, POM variation was explained equally well by a combination of a sinusoidal diel plus either temperature or nutricline depth model (Supplementary Fig. 5, Supplementary Fig. 6, Supplementary Table 4, Supplementary Table 5). The models lent support for both the translation-compensation and nutrient supply hypotheses. As such, we were statistically unable to distinguish between these two ecological stoichiometry hypotheses based solely on our Indian Ocean data.

To further understand how POM stoichiometry was regulated, we next compared the observed relationships for environmental variation and POM composition within the Indian Ocean with previously seen global trends ${ }^{1}$ (Fig. 5, Supplementary Fig. 7). While the nutricline depth was positively related to POM elemental ratios for both the Indian Ocean and globally, the relationship for temperature flipped from negative in the Indian Ocean to globally positive. This suggests that the relationship between temperature and POM stoichiometry is not uniform. We further searched the global C:N:P database for all surface transects with strong temperature and nutricline depth correlations (Supplementary Fig. 8). This analysis confirmed the observations in the Indian Ocean, whereby the correlation between nutricline depth and POM stoichiometry was consistently positive. In contrast, the correlation between temperature 


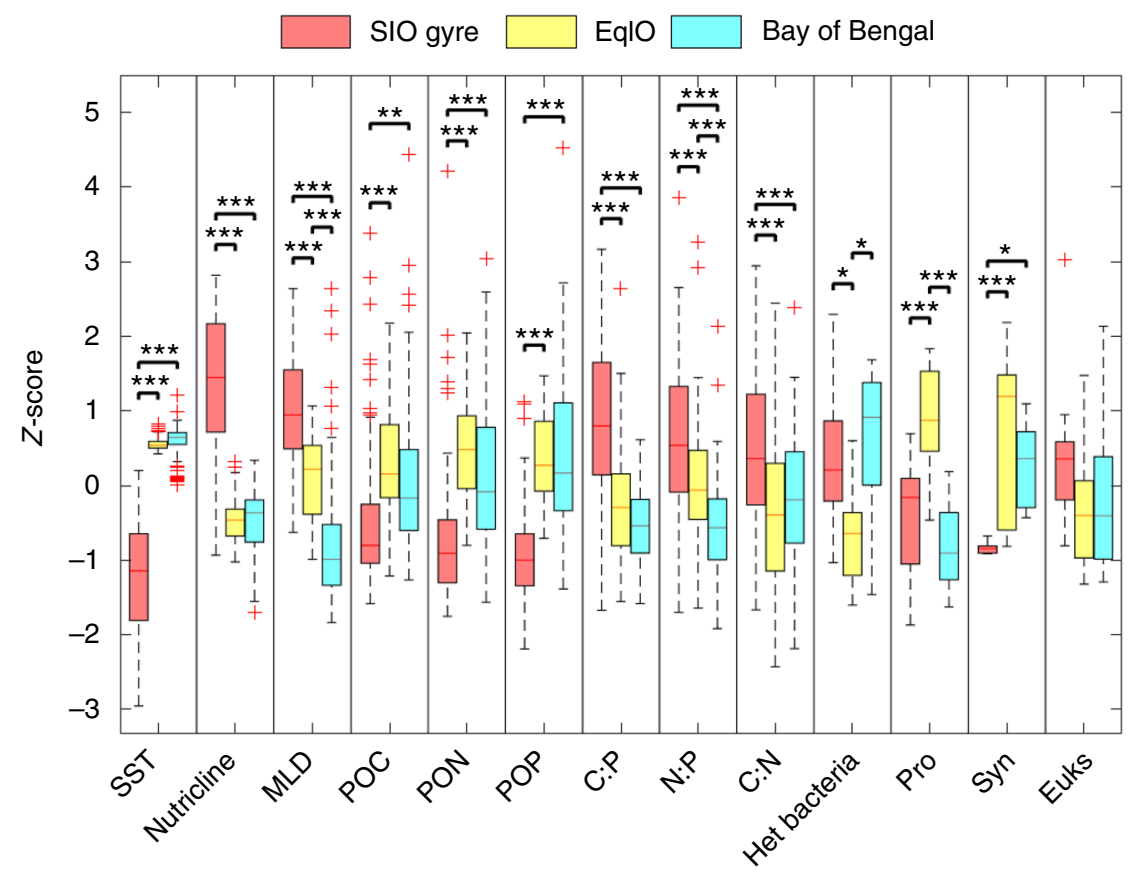

Fig. 4 Regional variation in environmental parameters, relative biomass, and POM concentrations and ratios. Significant regional variation between specific regions is indicated by the number of stars (ANOVA, ${ }^{\star} p<0.5,{ }^{\star \star} p<0.01,{ }^{\star \star \star} p<0.001$ ). For relative biomass; Het bacteria $=$ heterotrophic bacteria, Pro $=$ Prochlorococcus, Syn $=$ Synechococcus, and Euks = Eukaryotes

and POM stoichiometry could be both positive and negative, leading us to reject the translation-compensation hypothesis. It is worth noting that all these cruises were from tropical and subtropical ocean leaving it currently unknown how temperature vs. nutrient supply control higher latitude POM ratios. Nevertheless, the analysis suggests that for at least low latitude regions, nutrient availability is the primary control on POM stoichiometry.

Proposed model relating N:P supply ratio to gyre POM C:N:P. While the POM C:P and N:P ratios in SIO were above Redfield proportions, they were still substantially lower than observed in several other low nutrient ocean regions. To further understand the biogeochemical controls on POM cycling, we compared the POM concentrations and ratios in SIO gyre to the North Atlantic, South Atlantic, North Pacific, and South Pacific subtropical gyres (Fig. 6, Supplementary Fig. 9). The mean gyre concentration for POC, PON, and POP was $3.1 \mu \mathrm{M}, 0.37 \mu \mathrm{M}$, and $16 \mathrm{nM}$ respectively and our observed concentrations in the SIO gyre were generally consistent with these levels (Supplementary Table 6). However, there was also a clear difference in the levels and ratios across gyres (Supplementary Table 7, ANOVA $p$-values $<1 \mathrm{E}-16)$. The South Indian and North Pacific observations had anomalously low median POM concentrations, the North Atlantic was near the mean, and the South Pacific and South Atlantic gyres had median POM concentrations at or above the means. Median C:P and N:P ratios were near or slightly above Redfield proportions in the SIO gyre (C:P $=147: 1$, $\mathrm{N}: \mathrm{P}=19: 1)$, near the average in the North and South Pacific, and elevated in the North Atlantic subtropical gyre (C:P = 205:1, $\mathrm{N}: \mathrm{P}=33: 1$ ) (no POP data for the South Atlantic). Median C:N ratios ranged from 6.9 (North Atlantic gyre) to 9.0 (South Atlantic gyre). The highest C:N ratios were found in the gyres with the highest median POM concentrations. Thus, there were significant differences in POM ratios across gyres (Supplementary Table 7).
We hypothesized that low iron ( $\mathrm{Fe}$ ) supply could influence the elemental ratios via $\mathrm{Fe}$-controls on regional $\mathrm{N}_{2}$-fixation rates and the relative degree of $\mathrm{N}$ vs. $\mathrm{P}$ stress (Fig. 7$)^{20}$. In regions with low $\mathrm{N}_{2}$-fixation rates, a relatively higher $\mathrm{P}$ vs. $\mathrm{N}$ availability would lead to lower POM C:P and vice-versa for regions with high rates leading to high POM C:P. Thus, Fe controls on $\mathrm{N}_{2}$-fixation may influence the nutrient supply ratio of nitrogen vs. phosphorus which in turn would affect POM C:P5. Previously measured dissolved $\mathrm{Fe}$ concentrations ${ }^{11,21}$ in subtropical gyres have an inverse relationship with surface phosphate ${ }^{22}$ (Fig. 7a). Here, the South Indian and South Pacific gyres have the highest phosphate concentrations, but lowest dissolved iron concentrations. The lowest PO4:Dfe concentration ratio was found in the North Atlantic gyre. To begin to evaluate this hypothesis, we measured ratios of POM iron to carbon and phosphorus. We detected lower labile particulate iron to POC (LPFe:C) ratios in the SIO gyre $(17.8 \mathrm{nM} / \mu \mathrm{M})$ and typical of a low iron ecosystem (Supplementary Table 1). This was seen for both labile and refractory pFe. In contrast, pFe:C was elevated in the $\mathrm{EqIO}(22.3 \mathrm{nM} / \mu \mathrm{M})$ region and further increased into the BoB $(44.5 \mathrm{nM} / \mu \mathrm{M})$ (Supplementary Table 1). Thus, there appeared to be lower iron stress north of EqIO and the highest degree of iron stress in the gyre. As such, the C:P ratio in the SIO compared to the North Atlantic gyre may be depressed due to lower Fe, lower $\mathrm{P}$, and higher $\mathrm{N}$ availability (Fig. 7b, c). The regional LPFe:C and LPFe:P mean ratios increased toward the north, further indicating reduced iron stress in the phytoplankton community in EqIO and BoB (Supplementary Table 6). Thus, the elevated iron stress in the South Indian Ocean may suppress C:P in the gyre.

\section{Discussion}

The quantification of POM concentrations in the eastern Indian Ocean allowed us to test current hypotheses for how elemental ratios are regulated as well as identify regional differences in biogeochemical functioning. Our findings directly evaluate three proposed mechanisms (allometric diversity, temperature, and 

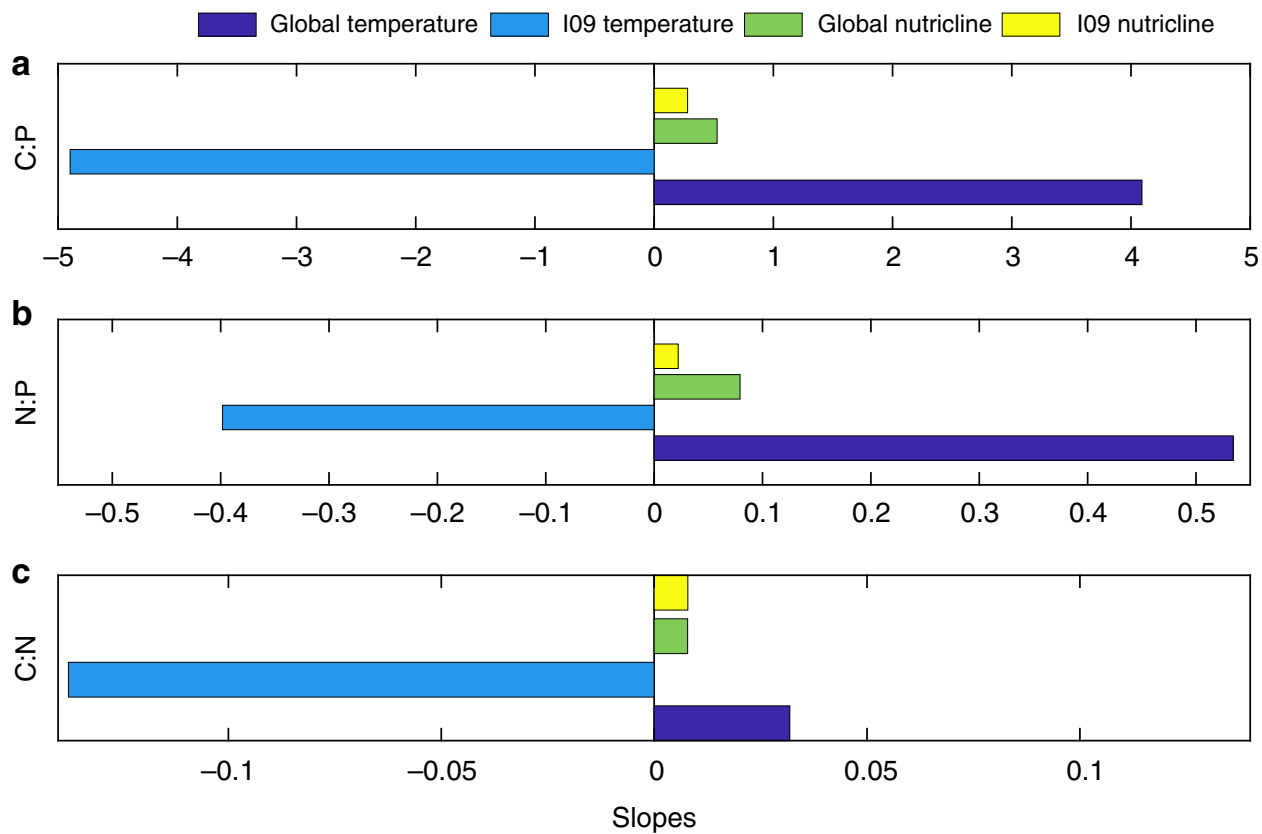

Fig. 5 Global and Indian Ocean environmental correlations. Mean of slope estimates for global and Indian Ocean (IO9N) transect particulate organic matter (POM) concentrations and ratios. The sign of the slope indicates the average relationship between the POM concentration (ratio) and the environmental parameter (temperature or nutricline depth). Slopes are fitted to a linear regression model (see Methods)

nutrient supply) that may explain deviations in POM stoichiometry. Consistent with past studies ${ }^{23,24}$, Prochlorococcus dominated the phytoplankton community and the ratio of photo-toheterotrophic plankton biomass was nearly 1:1 throughout the transect. Thus, we only observed minor changes in the community structure leading us to reject the allometric diversity hypothesis. However, there are caveats to this conclusion. First, genetic diversity within groups (e.g., ecotypes) may determine growth physiology leading to unique elemental composition ${ }^{25}$. However, no systematic patterns have yet been determined at this level of phylogenetic resolution. Secondly, heterotrophic bacteria did constitute a slightly larger portion of the relative biomass when C:P and C:N ratios were higher. We find this an unlikely driver as heterotrophic bacteria tend to have lower C:nutrient ratios in comparison to phytoplankton due to $\mathrm{C}$ limitation ${ }^{5,26}$. Thus, there is little support that changes in plankton community composition is the primary control on POM stoichiometry in this region.

The unique environmental conditions in the Indian Ocean lead us to support the nutrient supply hypothesis for low latitude marine ecosystems. For this analysis, we assumed nutricline depth was a proxy for nutrient supply rates to the surface and that a deeper nutricline would be indicative of increased surface nutrient stress. We found that the C:P, N:P, and C:N ratios were highest in the SIO gyre and decreased when the nutricline shoaled around $10-12^{\circ} \mathrm{S}$. Northwards of this latitude, the Indian Ocean is subject to monsoonal circulation patterns and fine-scale variation in the elemental ratios corresponded to observed changes in the nutrient supply. All of the ratios remained above Redfield proportions, reflecting oligotrophic surface conditions during the inter-monsoon season. Between $5^{\circ} \mathrm{S}$ and $5^{\circ} \mathrm{N}, \mathrm{C}: \mathrm{P}$ and $\mathrm{C}: \mathrm{N}$ ratios increased when nutrient concentrations declined below the mixed layer, but the ratios were elevated at the equator where a band of high chlorophyll was present off Sumatra. While the onset of upwelling in the tropical Indian Ocean is consistent, the magnitude is seasonally variable and underlying mechanisms are complex $^{27-31}$. Furthermore, the positive phase of the Indian Ocean Dipole can influence surface circulation as well ${ }^{15,29}$.
Historically, upwelling is also observed off Sri Lanka Dome near $5^{\circ} \mathrm{N}$, where POM concentrations were the highest and elemental ratios decreased ${ }^{13,30}$. Within the $\mathrm{BoB}$, the elemental ratios flattened out in the stratified Inter-Monsoon gyre until a final increase putatively driven by increased nutrient supply over the continental shelf in northern BoB. Thus, regional differences in the nutrient supply rates indicated by nutricline depth across the eastern Indian Ocean appeared to regulate POM concentrations and ratios.

Two cruise transects in the North Atlantic shared a positive relationship between temperature and nutrient supply and these provide further support of our hypothesis for how POM ratios are regulated. POM elemental ratios were reported as part of a FS Poseidon (Kahler) ${ }^{32}$ cruise $\left(30^{\circ} \mathrm{W}, 18^{\circ} \mathrm{N}-31^{\circ} \mathrm{N}\right)$ and a North Atlantic Bloom Experiment (NABE) ${ }^{33}$ cruise $\left(33^{\circ} \mathrm{N}, 21^{\circ} \mathrm{W}-18^{\circ} \mathrm{N}\right.$, $\left.30^{\circ} \mathrm{W}\right)$. In both of these cruises, nutrient supply rates were the best predictor for POM ratios and the temperature relationship flipped in comparison to global trends (Supplementary Fig. 8). Since macronutrient supply rates are non-limiting in high latitude regions, other factors (e.g., light, temperature, and plankton growth physiology) likely control C:N:P in such biomes ${ }^{5,34}$. In support, a recent study demonstrated that the elemental composition of a phytoplankton was highly regulated by the nutrient supply but the optimal composition (i.e., N:P at maximum growth) was temperature dependent ${ }^{35}$. Thus, there could be an interaction leading to a more pronounced temperature effect in high nutrient conditions, but we reject the translationcompensation hypothesis as the primary driver in low latitude regions.

Stoichiometric variation on diel time scales was observed throughout the region. In support, studies of phytoplankton cultures $^{36-38}$ and communities ${ }^{38-41}$ show a peak in the carbonnutrient ratio towards the end of the photoperiod. A diel range in $\mathrm{C}: \mathrm{P}$ of 60 and C:N of 2 were found in Synechococcus cultures, but barely any variation in the N:P ratio ${ }^{36}$. The peaks are primarily attributed to daytime fixed carbon storage and troughs from exudation and respiration at night ${ }^{36,42}$. The amplitude of C:P and $\mathrm{C}: \mathrm{N}$ were larger in a culture than observed in the IO9N transect, 

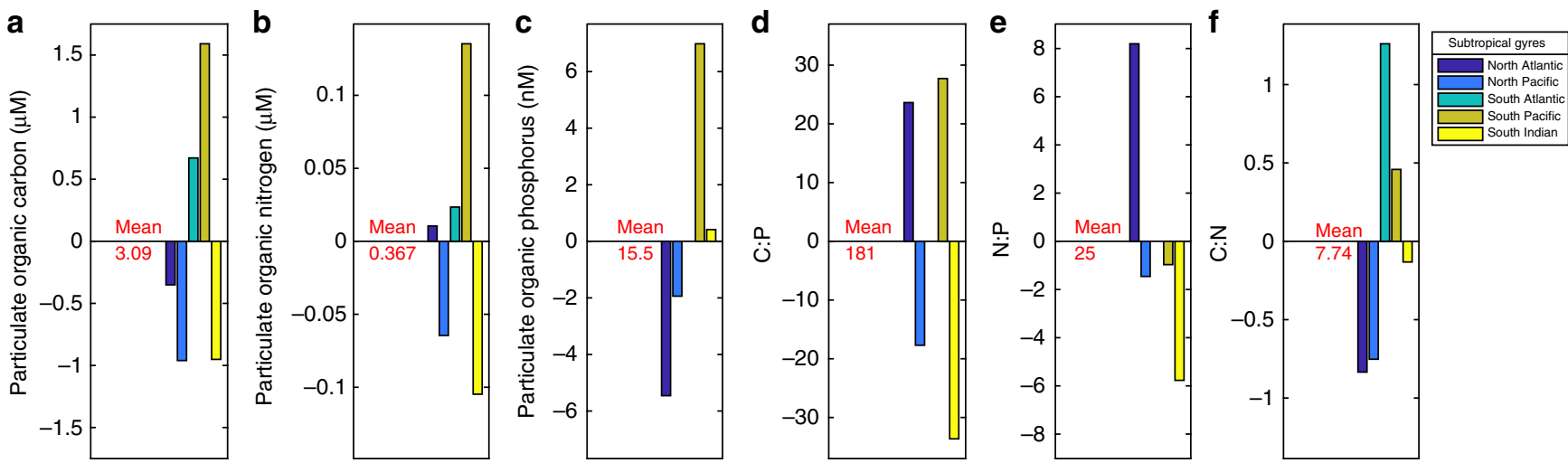

Fig. 6 Gyre anomalies for particulate organic matter concentration and ratios. Anomalies are relative to gyre mean (red text) for a particulate organic carbon (POC), b particulate organic nitrogen (PON), c particulate organic phosphorus (POP), d POC:POP (C:P), e PON:POP (N:P), and f POC:PON (C:N). There are no POP, C:P, or N:P data for the South Atlantic gyre

which may be due to the presence of heterotrophic lineages or detrital material in field samples. The diel cycling of POC accumulation and degradation could also influence nutrient cycling within the whole microbial community. Diel changes in the surface area to volume ratio of phytoplankton can limit their nutrient uptake and the timing of their release of photosynthetically-derived nutrients can directly impact the ambient nutrient concentrations for heterotrophic bacteria. In addition, heterotrophic grazers could compensate for low-quality prey (high C:N, C:P) by increased feeding at night ${ }^{38}$. It was unclear if the N:P ratio residuals displayed a diel cycle leading us to conclude that daily $\mathrm{N}$ and $\mathrm{P}$ uptake was fairly synchronized in this region. If $\mathrm{N}$ fixation played a large role during the IO9N transect, we would expect the N:P ratio to increase during the daytime $\mathrm{e}^{43}$ but the absence of this trend suggested depressed $\mathrm{N}$ fixation rates. Our results illustrate that the amplitude of daily C:P and $\mathrm{C}: \mathrm{N}$ peaks is of a comparable magnitude to changes in the ratios across ocean regions, but the lack of N:P cycling indicates a constraint on additional $\mathrm{N}$ inputs.

We hypothesized that low Fe supply depresses the elemental ratios via controls on $\mathrm{N}_{2}$-fixation rates and the relative degree of $\mathrm{N}$ vs. $\mathrm{P}$ stress $^{20}$. In contrast, high $\mathrm{Fe}$ inputs and increased nitrogen fixation may lead to elevated $\mathrm{N}$ and intense $\mathrm{P}$ drawdown. We propose that this mechanism leads to divergent C:P and N:P ratios in the North Atlantic Ocean vs. the South Indian Ocean gyre. In the eastern Indian Ocean, the regional LPFe:C and LPFe: $\mathrm{P}$ mean ratios increased toward the north, indicating northward positive gradient iron availability for the phytoplankton community (Supplementary Table 1). Higher N-fixation rates in the Arabian Sea than at the equator and SIO gyre along $69^{\circ} \mathrm{E}$ were attributed to higher dissolved iron in the Arabian $\mathrm{Sea}^{44}$. Our depressed C:P ratios in the SIO gyre are consistent with inverse model results and observations of the western SIO gyre ${ }^{4,40}$. Thus, the SIO gyre may represent a low C:P extreme for ocean gyres. As such, the variations in particulate elemental ratios observed in the Indian Ocean are distinctive and impose new constraints on how ocean C:N:P is regulated.

\section{Methods}

Sample collection and analysis procedures. Seawater samples were collected during the RR1604 GO-SHIP IO9N cruise aboard $R / V$ Roger Revelle from March $22-$ April 24, 2016. Transect coordinates began at $31^{\circ} 02^{\prime} 01^{\prime \prime} \mathrm{S} / 110^{\circ} 27^{\prime} 28^{\prime \prime} \mathrm{E}$ off Western Australia and ended at $16^{\circ} 44^{\prime} 15^{\prime \prime} \mathrm{N} / 90^{\circ} 08^{\prime} 77^{\prime \prime} \mathrm{E}$ in the BoB (Fig. 1). In total, samples for POC, PON, and POP were taken at 238 stations. Samples for particulate iron were collected from 24 separate trace-metal clean casts off the stern at $20 \mathrm{~m}$ depth. Flow cytometry samples for phytoplankton and bacteria cell counts were collected from the mixed layer $(\sim 20 \mathrm{~m})$ at $31 \mathrm{GO}-\mathrm{SHIP}$ stations. All cruise POM data is available on BCO-DMO (https://www.bco-dmo.org/dataset/734915).
Nutrients data for this cruise were provided by Jim Swift/SIO and Susan Becker/ SIO and is available at https://cchdo.ucsd.edu ${ }^{45}$.

Water was collected from a circulating seawater system distributed via plastic tubing for POC/PON/POP around $3 \mathrm{~m}$ deep. An underway system was chosen to vastly increase sampling coverage, replicate number, and sample volume. The water intake is located near the ship sea chest, which may have missed particle production in the subsurface. The circulating seawater was never turned off during the entirety of the transect and kept at a constant flow. Water was passed through a $30 \mu$ m nylon mesh (Small Parts \#7050-1220-000-12) to remove larger plankton and particles from the sample. Each replicate was collected into a separate $8.5 \mathrm{~L}$ plastic carboys (Thermo Scientific, Waltham, MA). In between stations, carboys were rinsed with $30 \mu \mathrm{m}$ filtered sample water just prior to collection. Six $8 \mathrm{~L}$ seawater samples were divided into POC/PON and POP triplicates. Carboys were placed at $\sim 45^{\circ}$ angle to avoid particle settling below the nozzle. Each replicate was passed through a $25 \mathrm{~mm}$ pre-combusted $\left(500^{\circ} \mathrm{C}\right.$ for $5 \mathrm{~h}$ ) GF/F filter (Whatman, Florham Park, NJ) with a nominal pore size of $0.7 \mu \mathrm{m}$. The vacuum filtration was an in-line setup with $25 \mathrm{~mm}$ filter holders connected to an aspirator pump at $-0.08 \mathrm{MPa}$. POP filters were rinsed with $5 \mathrm{~mL}$ of $0.17 \mathrm{M} \mathrm{Na}_{2} \mathrm{SO}_{4}$ to remove traces of dissolved phosphorus from the filter. All filters were stored in pre-combusted aluminum packets and immediately frozen at $-80^{\circ} \mathrm{C}$ during the cruise and $-20^{\circ} \mathrm{C}$ for shipment.

Particulate organic carbon/nitrogen. Prior to analysis, the filters for POC and PON were dried according to the JGOFS protocol ${ }^{46}$. The protocol has a detection range of $0.43-43.13 \mu \mathrm{M}$ for POC and $0.037-7.39 \mu \mathrm{M}$ for PON in sea water ${ }^{46}$. First, the filters were dried in an incubator at $55^{\circ} \mathrm{C}$ for $24-48 \mathrm{~h}$ and then stored in a desiccator with concentrated $\mathrm{HCl}$ fumes for $24 \mathrm{~h}$ to remove inorganic carbonates. Secondly, the filters were dried again at $55^{\circ} \mathrm{C}$ for $48 \mathrm{~h}$ before being folded and packed into pre-combusted tin capsules (CE Elantech, Lakewood, NJ). The packaged filters are analyzed on a CN FlashEA 1112 Elemental Analyzer (Thermo Scientific, Waltham, MA) against an atropine standard curve (chemical formula $\mathrm{C}_{17} \mathrm{H}_{23} \mathrm{NO}_{3}$ ).

Particulate organic phosphorus. POP was analyzed according to a modified ashhydrolysis protocol ${ }^{47}$. Thawed filters were placed in along with a corresponding standard curve of $\mathrm{KH}_{2} \mathrm{PO}_{4} .2 \mathrm{~mL}$ of $0.017 \mathrm{M} \mathrm{MgSO}_{4}$ was added to the acid-washed glass vials containing filters and covered with pre-combusted aluminum foil. The vials were placed in an incubator at $90^{\circ} \mathrm{C}$ for $24 \mathrm{~h}$ and then combusted $\left(500{ }^{\circ} \mathrm{C}, 2\right.$ h). Once cooled, $5 \mathrm{~mL} 0.2 \mathrm{M} \mathrm{HCl}$ was added and incubated at $90^{\circ} \mathrm{C}$ for at least 30 min. Next, the supernatant plus $5 \mathrm{~mL}$ Milli-Q water was mixed with 2:5:1:2 parts ammonium molybdate tetrahydrate, $5 \mathrm{~N}$ sulfuric acid, potassium antimonyl tartrate, and ascorbic acid for $30 \mathrm{~min}$. Finally, the standards and samples were analyzed on a spectrophotometer at a wavelength of $885 \mathrm{~nm}$ to determine POP concentration with an assay detection limit $0.1 \mathrm{nmol} \mathrm{L}^{-1}$.

C:N, C:P, and N:P ratios. Each filter analyzed for both POC and PON was treated as a replicate with a corresponding POC/PON ratio. The ratios of POC/POP and PON/POP were taken from the mean concentrations. The standard deviation for $\mathrm{C}: \mathrm{P}$ and $\mathrm{N}: \mathrm{P}$ was calculated as a pooled sample:

$$
\begin{gathered}
\sigma_{\mathrm{CN}}=\sqrt{ }\left(\left(\Sigma\left(\mathrm{CN}_{i}-\mathrm{CN}_{\text {ave }}^{2}\right)\right) / n\right), \\
\sigma_{\mathrm{NP}}=\mathrm{N}_{\mathrm{ave}} / \mathrm{P}_{\mathrm{ave}} \times\left(\sqrt{ }\left(\left(\sigma_{\mathrm{N}} / \mathrm{N}_{\mathrm{ave}}\right)^{2}+\left(\sigma_{\mathrm{P}} / \mathrm{P}_{\mathrm{ave}}\right)^{2}\right)\right), \\
\sigma_{\mathrm{CP}}=\mathrm{C}_{\mathrm{ave}} / \mathrm{P}_{\mathrm{ave}} \times\left(\sqrt{ }\left(\left(\sigma_{\mathrm{C}} / \mathrm{C}_{\mathrm{ave}}\right)^{2}+\left(\sigma_{\mathrm{P}} / \mathrm{P}_{\text {ave }}\right)^{2}\right)\right),
\end{gathered}
$$




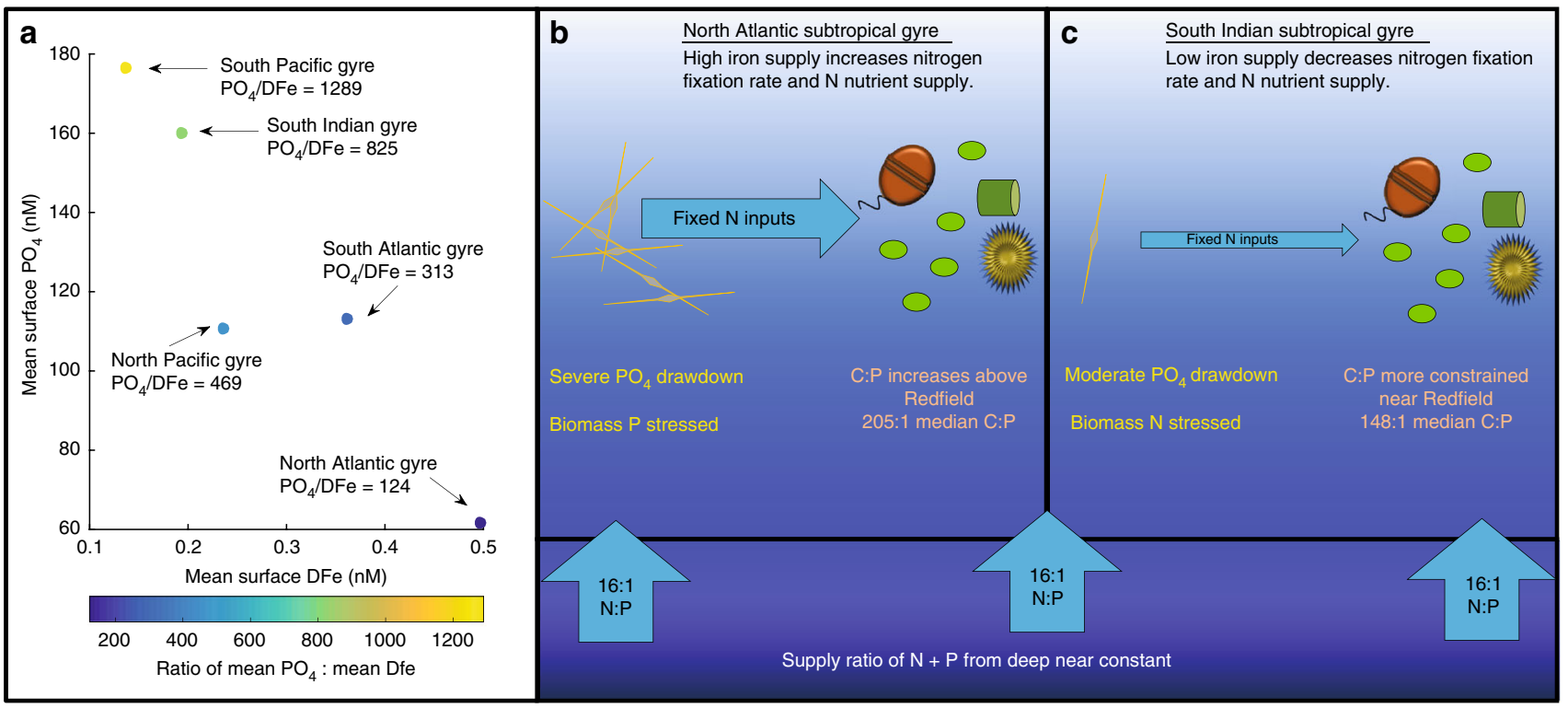

Fig. 7 Conceptual model for regulation of ocean gyre biogeochemistry. a Nutrient levels across gyres: median surface phosphate to dissolved iron in top $50 \mathrm{~m}$. b Iron supply model for C:P in North Atlantic and c South Indian Ocean subtropical gyres. Median C:P values are from gyre comparison (North Atlantic, Supplementary Table 6) and this cruise

Relative biomass estimates. Samples for biomass were collected directly into $2 \mathrm{~mL}$ cryovials from Niskin bottles at sea, and fixed with freshly made and $0.2 \mu \mathrm{m}$ filtered paraformaldehyde. After fixation for $1 \mathrm{~h}$ at $4{ }^{\circ} \mathrm{C}$ in the dark, samples were frozen at $-80^{\circ} \mathrm{C}$ until analysis. Cell counts were run on a BD FACSJazz flow cytometer equipped a $200 \mathrm{~mW} 488 \mathrm{~nm}$ laser. Prochlorococcus was determined by forward scatter and red fluorescence, and Synechococcus distinguished by emission in the green and yellow wavelengths. Small eukaryotes were the autofluorescing cells outside of the cyanobacterial gates. Biomass estimates were based on literature values of carbon per cell based on geometric means of forward scatter for each group ${ }^{48}$. Relative biomass estimates were used in this study.

Particulate and dissolved Fe. Trace metal samples were collected from $5 \mathrm{~L}$ Teflon-coated Niskin-X bottles hung on Kevlar line. Niskin bottles were transferred to a clean bubble immediately after sample collection. Samples for dissolved metal analysis were filtered through acid-washed $0.4 \mu \mathrm{m}$ polycarbonate filters using a vacuum filtration apparatus and acidified using Optima grade $\mathrm{HCl}$. Particulate samples were collected by filtering directly from pressurized Niskin bottles onto $0.45 \mu \mathrm{m}$ Supor membranes. All samples were handled and stored using trace metal clean protocols. Dissolved samples were analyzed using an ESI seaFAST SP2 coupled to a Perkin Elmer Nexion 350D ICP-MS. Samples were passed through an ESI preconcentration column and buffered in-line with ammonium acetate buffer. Metals were eluted off the column and analyzed in DRC mode using ammonia gas. Samples were quantified using standard additions; each sample was spiked with two additions averaging roughly $100 \%$ and $200 \%$ of the sample concentration. Labile particulate metals were leached ${ }^{49}$ and were analyzed using a Thermo Element 2 HR-ICP-MS ${ }^{50}$.

Statistical model analysis. All analyses were completed in MATLAB. Nutricline depth was chosen as a proxy for nutrient supply, and was determined by a threshold nitrate concentration of $1 \mu \mathrm{M}$. Depth profiles of nitrate concentrations were analyzed using an AutoAnalyzer shipboard, run by the SIO HydroLab according to standard methods ${ }^{51}$. Mixed layer depths (MLD), isothermal layer depths, and barrier layer thickness were calculated according to Rao and Sivakumar ${ }^{52}$ (Supplementary Fig. 4). MLD is the depth where the change in potential density anomaly $\left(\sigma_{t}\right)$ equals the surface $\sigma_{t(z=0)}$ plus a change in $0.5^{\circ} \mathrm{C}(\Delta T)$ times the thermal expansion coefficient $(\mathrm{d} \sigma / \mathrm{d} t)$.

Mixed layer depth (MLD), where $\sigma_{t(z=h)}=\sigma_{t(z=0)}+\Delta T \mathrm{~d} \sigma / \mathrm{dt}$,

Isothermal layer depth (ITL), where $\theta=\theta_{(z=0)}+\Delta T$,

Barrier layer thickness $(\mathrm{BLT})=\mathrm{ITL}-\mathrm{MLD}$,
SST values were from the underway temperatures by the Hydro Lab (HLT) using the following correction ${ }^{53}$ :

$$
\operatorname{SST}(\text { estimated })=0.001424 * \mathrm{HLT}^{2}+0.950053 * \mathrm{HLT}+0.048227,
$$

Statistical models were fitted using one or two predictor variables (SST $\left({ }^{\circ} \mathrm{C}\right)$, nutricline depth (m), or MLD, as well as time) (Supplementary Table 5). The models were also fitted against all stations south of $5^{\circ} \mathrm{N}$ to examine the influence from the BoB on the fits (Supplementary Table 6). RMSE and $R^{2}$ were used to compare across models. If a daily diel rhythm was identified (Supplementary Table 1, Supplementary Fig. 3), a sine function was added to the model with a fixed period of $24 \mathrm{~h}$.

$$
\begin{aligned}
& y=p(1)_{y} * \sin \left(\frac{\text { Tot Hrs } * 2 \pi}{24}+p(2)_{y}\right)+\left(p(3)_{y}+p(4)_{y} \times(\text { SST, Znut, or MLD }),\right. \\
& \text { where } y=\text { POC, PON, POP, C }: \text { P, C : N, or N : P }
\end{aligned}
$$

Residuals between the points and 8-point moving average were used for comparing the diel cycles of POM concentrations and ratio at each station. Again, most of the variation could be equally explained by temperature or nutricline depth. Residuals between the points and 8-point moving average were used for comparing the diel cycles of POM concentrations and ratio at each station.

Global and gyre comparisons. The global observations of concentrations and ratios of POM were from updated POM database ${ }^{54}$. Nitrate concentrations and temperature values were taken at the nearest depth from monthly WOA13 values at $1 \mathrm{~km}$ resolution ${ }^{22,55}$. For the gyre comparison, gyre coordinates were determined where the nutricline depth was greater than $150 \mathrm{~m}$ for the North Atlantic, South Atlantic, North Pacific, South Pacific, and South Indian Oceans. The latitude blocks for each gyre are as follows: North Atlantic $\left(90^{\circ} \mathrm{W}\right.$ to $\left.5^{\circ} \mathrm{W}\right)$; North Pacific $\left(120^{\circ} \mathrm{E}\right.$ to $\left.100^{\circ} \mathrm{W}\right)$; South Atlantic $\left(60^{\circ} \mathrm{W}\right.$ to $\left.10^{\circ} \mathrm{E}\right)$; South Pacific $\left(60^{\circ} \mathrm{W}\right.$ to $\left.150^{\circ} \mathrm{E}\right)$; South Indian $\left(30^{\circ} \mathrm{E}\right.$ to $\left.150^{\circ} \mathrm{E}\right)$. A map and boxplot of observations from each gyre and the new Indian Ocean values are shown in Supplementary Fig. 7. Average gyre surface phosphate concentrations were taken from $0 \mathrm{~m}$ WOA13 values over each gyre area (Fig. 7$)^{22}$. Average gyre surface dissolved iron concentrations were taken from all data point in the top $50 \mathrm{~m}$ over each gyre surface area using the more recent Tagliabue et al. database ${ }^{21}$. For the global comparison, POM observations were filtered to only include the top $30 \mathrm{~m}$. Temperature and nutricline values were paired with the observations and normalized to the maximum values. Correlation coefficients and slopes were determined separately for the global database stations and the new Indian Ocean observations (Fig. 5). The slopes were determined from a linear regression using a Monte Carlo Metropolis-Hastings algorithm developed for MatlabStan ${ }^{56,57}$. The scatter plots, linear fits and correlations are shown in Supplementary Fig. 6.

\section{Data availability}

Particulate organic matter data that support the findings of this study has been deposited in BCO-DMO as cited: Martiny, Adam and Lomas, Michael (2018) Particulate organic matter (PON, POC, POP) concentrations collected on R/V 
Roger Revelle cruise RR1604 along the hydrographic line IO9 in the eastern Indian Ocean from March to April 2016. Biological and Chemical Oceanography Data Management Office (BCO-DMO) https://www.bco-dmo.org/dataset/734915. Data for the GO_SHIP line I09N can be found at https://cchdo.ucsd.edu/.

Received: 7 November 2017 Accepted: 14 September 2018

Published online: 19 November 2018

\section{References}

1. Martiny, A. C. et al. Strong latitudinal patterns in the elemental ratios of marine plankton and organic matter. Nat. Geosci. 6, 279-283 (2013).

2. Weber, T. S. \& Deutsch, C. Ocean nutrient ratios governed by plankton biogeography. Nature 467, 550-554 (2010).

3. Martiny, A. C., Vrugt, J. A., Primeau, F. W. \& Lomas, M. W. Regional variation in the particulate organic carbon to nitrogen ratio in the surface ocean. Glob. Biogeochem. Cycles 27, 723-731 (2013).

4. Teng, Y.-C., Primeau, F. W., Moore, J. K., Lomas, M. W. \& Martiny, A. C. Global-scale variations of the ratios of carbon to phosphorus in exported marine organic matter. Nat. Geosci. 7, 895-898 (2014).

5. Moreno, A. R. \& Martiny, A. C. Ecological stoichiometry of ocean plankton. Annu. Rev. Mar. Sci. 10, 1-27 (2018)

6. Toseland, A. et al. The impact of temperature on marine phytoplankton resource allocation and metabolism. Nat. Clim. Change 3, 979-984 (2013).

7. Galbraith, E. D. \& Martiny, A. C. A simple nutrient-dependence mechanism for predicting the stoichiometry of marine ecosystems. Proc. Natl Acad. Sci. U. S.A. 112, 8199-8204 (2015).

8. Klausmeier, C. A., Litchman, E. \& Levin, S. A. Phytoplankton growth and stoichiometry under multiple nutrient limitation. Limnol. Oceanogr. 49 1463-1470 (2004)

9. Arrigo, K. R. Marine microorganisms and global nutrient cycles. Nature 437, 349-355 (2005).

10. Behrenfeld, M. J. \& Falkowski, P. G. Photosynthetic rates derived from satellite-based chlorophyll concentration. Limnol. Oceanogr. 42, 1-20 (1997).

11. Grand, M. M. et al. Dissolved $\mathrm{Fe}$ and $\mathrm{Al}$ in the upper $1000 \mathrm{~m}$ of the eastern Indian Ocean: a high-resolution transect along $95^{\circ} \mathrm{E}$ from the Antarctic margin to the Bay of Bengal. Glob. Biogeochem. Cycles 29, 375-396 (2015).

12. Lee, T. Decadal weakening of the shallow overturning circulation in the South Indian Ocean. Geophys. Res. Lett. 31, L18305 (2004).

13. Schott, F. A., Dengler, M. \& Schoenefeldt, R. The shallow overturning circulation of the Indian Ocean. Prog. Oceanogr. 53, 57-103 (2002).

14. Gomes, H. R., Goes, J. I. \& Saino, T. Influence of physical processes and freshwater discharge on the seasonality of phytoplankton regime in the Bay of Bengal. Cont. Shelf Res. 20, 313-330 (2000).

15. Wiggert, J. D., Vialard, J. \& Behrenfeld, M. J. Basin-wide Modification of Dynamical and Biogeochemical Processes by the Positive Phase of the Indian Ocean Dipole During the SeaWiFS Era. (eds Wiggert, J. D. et al.) 385-407 (American Geophysical Union (AGU), 2013)

16. Cermeño, P. et al. The role of nutricline depth in regulating the ocean carbon cycle. Proc. Natl Acad. Sci. USA. 105, 20344-20349 (2008).

17. NASA Goddard Space Flight Center, Ocean Ecology Laboratory, Ocean Biology Processing Group. Moderate-resolution Imaging Spectroradiometer (MODIS) Aqua Chlorophyll a $4 \mathrm{~km}$ Data. NASA OB.DAAC, Greenbelt, MD, USA. https://doi.org/10.5067/AQUA/MODIS/L3M/CHL/2016. Accessed 22 Aug 2017.

18. Prasanna Kumar, S. et al. Why is the Bay of Bengal less productive during summer monsoon compared to the Arabian Sea? Geophys. Res. Lett. 29, 881-88-4 (2002)

19. Rusch, D. B., Martiny, A. C., Dupont, C. L., Halpern, A. L. \& Venter, J. C. Characterization of Prochlorococcus clades from iron-depleted oceanic regions. Proc. Natl Acad. Sci. USA. 107, 16184-16189 (2010).

20. Mather, R. L. et al. Phosphorus cycling in the North and South Atlantic Ocean subtropical gyres. Nat. Geosci. 1, 439-443 (2008).

21. Tagliabue, A. et al. A global compilation of dissolved iron measurements: focus on distributions and processes in the Southern Ocean. Biogeosciences 95194, 2333-2349 (2012)

22. Garcia, H. E. et al. World Ocean Atlas 2013. Volume 4: Dissolved Inorganic Nutrients (phosphate, nitrate, silicate). In NOAA Atlas NESDIS 76 (eds Levitus, S. \& Mishonov, A.) 25pp (2013)

23. Schlüter, L., Henriksen, P., Nielsen, T. G. \& Jakobsen, H. H. Phytoplankton composition and biomass across the southern Indian Ocean. Deep-Sea Res. Part I Oceanogr. Res. Pap. 58, 546-556 (2011).

24. Zwirglmaier, K. et al. Global phylogeography of marine Synechococcus and Prochlorococcus reveals a distinct partitioning of lineages among oceanic biomes. Environ. Microbiol. 10, 147-161 (2008).
25. Martiny, A. C., Ma, L., Mouginot, C., Chandler, J. W. \& Zinser, E. R. Interactions between thermal acclimation, growth rate, and phylogeny influence prochlorococcus elemental stoichiometry. PLoS ONE 11, e0168291 (2016).

26. Makino, W., Cotner, J. B., Sterner, R. W. \& Elser, J. J. Are bacteria more like plants or animals? Growth rate and resource dependence of bacterial C:N:P stoichiometry. Funct. Ecol. 17, 121-130 (2003).

27. Strutton, P. G. et al. Biogeochemical variability in the central equatorial Indian Ocean during the monsoon transition. Biogeosciences 12, 2367-2382 (2015).

28. Wyrtki, K. An equatorial jet in the Indian Ocean. Science 181, 262-264 (1973).

29. Deshpande, A., Gnanaseelan, C., Chowdary, J. S. \& Rahul, S. Interannual spring Wyrtki jet variability and its regional impacts. Dyn. Atmos. Oceans $\mathbf{7 8}$, 26-37 (2017)

30. Hood, R. R., Beckley, L. E. \& Wiggert, J. D. Biogeochemical and ecological impacts of boundary currents in the Indian Ocean. Prog. Oceanogr. 156, 290-325 (2017).

31. Punyu, V. R., Banakar, V. K. \& Garg, A. Equatorial Indian Ocean productivity during the last $33 \mathrm{kyr}$ and possible linkage to Westerly Jet variability. Mar. Geol. 348, 44-51 (2014)

32. Dietze, H., Oschlies, A. \& Kähler, P. Internal-wave-induced and doublediffusive nutrient fluxes to the nutrient-consuming surface layer in the oligotrophic subtropical North Atlantic. Ocean Dyn. 54, 1-7 (2004).

33. Passow, U. \& Peinert, R. The role of plankton in particle flux: two case studies from the northeast Atlantic. Deep-Sea Res. Part II Top. Stud. Oceanogr. 40, 573-585 (1993).

34. Rembauville, M., Blain, S., Caparros, J. \& Salter, I. Particulate matter stoichiometry driven by microplankton community structure in summer in the Indian sector of the Southern Ocean. Limnol. Oceanogr. 61, 1301-1321 (2016).

35. Thrane, J.-E., Hessen, D. O. \& Andersen, T. Plasticity in algal stoichiometry: experimental evidence of a temperature-induced shift in optimal supply N:P ratio. Limnol. Oceanogr. 62, 1346-1354 (2017).

36. Lopez, J. S., Garcia, N. S., Talmy, D. \& Martiny, A. C. Diel variability in the elemental composition of the marine cyanobacterium Synechococcus. J. Plankton Res. 38, 1052-1061 (2016)

37. Clark, D. R., Flynn, K. J. \& Fabian, H. Variation in elemental stoichiometry of the marine diatom Thalassiosira weissflogii (Bacillariophyceae) in response to combined nutrient stress and changes in carbonate chemistry. J. Phycol. 50, 640-651 (2014).

38. Ng, W. H. A. \& Liu, H. Diel periodicity of grazing by heterotrophic nanoflagellates influenced by prey cell properties and intrinsic grazing rhythm. J. Plankton Res. 38, fbw014 (2016).

39. Fraga, F. Distribution of particulate and dissolved nitrogen in the Western Indian Ocean. Deep-Sea Res. 13, 413-425 (1966).

40. Copin-Montegut, C. \& Copin-Montegut, G. The chemistry of particulate matter from the south Indian and Antarctic oceans. Deep-Sea Res. 25, 911-931 (1978).

41. Fuhrman, J., Eppley, R., Hagstrom, A. \& Azam, F. Diel variations in bacterioplankton, phytoplankton, and related parameters in the Southern California Bight. Mar. Ecol. Prog. Ser. 27, 9-20 (1985).

42. Granum, E., Kirkvold, S. \& Myklestad, S. M. Cellular and extracellular production of carbohydrates and amino acids by the marine diatom Skeletonema costatum: diel variations and effects of $\mathrm{N}$ depletion. Mar. Ecol. Prog. Ser. 242, 83-94 (2002)

43. Capone, D. G., O’Neil, J. M., Zehr, J. \& Carpenter, E. J. Basis for diel variation in nitrogenase activity in the marine planktonic cyanobacterium Trichodesmium thiebautii. Appl. Environ. Microbiol. 56, 3532-3536 (1990).

44. Shiozaki, T., Ijichi, M., Kodama, T., Takeda, S. \& Furuya, K. Heterotrophic bacteria as major nitrogen fixers in the euphotic zone of the Indian Ocean. Glob. Biogeochem. Cycles 28, 1096-1110 (2014).

45. Swift, J. \& Becker, S. I09N, 33RR20160321_hyl.csv, CLIVAR and Carbon Hydrographic Data Office, La Jolla, CA, USA. Available at: https://cchdo.ucsd. edu/cruise/33RR20160321. Accessed 06 Aug 2017.

46. Ducklow, H. \& Dickson, A. Shipboard sampling procedures. JGOFS 1-210 (1994).

47. Lomas, M. W. et al. Sargasso Sea phosphorus biogeochemistry: an important role for dissolved organic phosphorus (DOP). Biogeosciences 7, 695-710 (2010).

48. Casey, J. R., Aucan, J. P., Goldberg, S. R. \& Lomas, M. W. Changes in partitioning of carbon amongst photosynthetic pico- and nano-plankton groups in the Sargasso Sea in response to changes in the North Atlantic Oscillation. Deep-Sea Res. Part II Top. Stud. Oceanogr. 93, 58-70 (2013).

49. Berger, C. J. M., Lippiatt, S. M., Lawrence, M. G. \& Bruland, K. W. Application of a chemical leach technique for estimating labile particulate aluminum, iron, and manganese in the Columbia River plume and coastal waters off Oregon and Washington. J. Geophys. Res. 113, C00B01 (2008).

50. Twining, B. S. et al. Metal quotas of plankton in the equatorial Pacific Ocean. Deep-Sea Res. Part II Top. Stud. Oceanogr. 58, 325-341 (2011). 
51. Hydes, D. et al. Determination of dissolved nutrients (N, P, Si) in seawater with high precision and inter-comparability using gas-segmented continuous flow analysers. In The GO-SHIP Repeat Hydrography Manual: A Collection of Expert Reports and Guidelines Version 1, IOCCP Report No. 14, ICPO Publication Series No. 134 (eds Hood, E.M. et al.) 87 (2010).

52. Rao, R. R. \& Sivakumar, R. Seasonal variability of sea surface salinity and salt budget of the mixed layer of the north Indian Ocean. J. Geophys. Res. 108, 3009 (2003).

53. Wanninkhof, R., Sullivan, K. \& Pierrot, D. Underway $p \mathrm{CO}_{2}$ Measurements in Surface Waters and the Atmosphere During the R/V Roger Revelle GO-SHIP Cruise Along the Section I09N_2016 (March 21-April 27, 2016). Available at http://cdiac.ornl.gov/ftp/oceans/CLIVAR/I09N_33RR20160321/Underway/. (Carbon Dioxide Information Analysis Center, Oak Ridge National Laboratory, US Department of Energy, 2016).

54. Martiny, A. C., Vrugt, J. A. \& Lomas, M. W. Concentrations and ratios of particulate organic carbon, nitrogen, and phosphorus in the global ocean. Sci. Data 1, 140048 (2014).

55. Locarnini, R. A. et al. World Ocean Atlas 2013. Volume 1: Temperature. In NOAA Atlas NESDIS 73 (eds Levitus, S. \& Mishonov, A.) 40pp (2013).

56. Stan Development Team. MatlabStan: The MATLAB Interface to Stan. Available at http://mc-stan.org/matlab-stan.html (2017).

57. Carpenter, B. et al. Stan: a probabilistic programming language. J. Stat. Softw. 76, 1-32 (2017).

\section{Acknowledgements}

We thank K.H. Andersen, F. Primeau, and G. Britten for their helpful comments. We thank the captain and crew of the SCRIPPS R/V Roger Revelle, the chief scientists L. Barbero and C. Rodriguez, and the science party on board the IO9N cruise. We also thank GO-SHIP coordinators Lynne Talley and Greg Johnson for their support in participating in the U.S. Global Ocean Carbon and Repeat Hydrography Program. The work was supported by the National Aeronautics and Space Administration Earth and Space Science Fellowship (NESSF16R to C.A.G.) and NSF (OCE-1559002 to A.C.M. and OCE-1559021 to M.W.L. and B.S.T.).

\section{Author contributions}

C.A.G., A.C.M., M.W.L., and B.S.T. designed the research; C.A.G., S.E.B., N.S.G., and S.R. made the analytical measurements; C.A.G. conducted the data analysis; and C.A.G. and A.C.M. wrote the paper with input from all authors.

\section{Additional information}

Supplementary Information accompanies this paper at https://doi.org/10.1038/s41467018-06892-w.

Competing interests: The authors declare no competing interests.

Reprints and permission information is available online at http://npg.nature.com/ reprintsandpermissions/

Publisher's note: Springer Nature remains neutral with regard to jurisdictional claims in published maps and institutional affiliations.

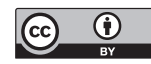

Open Access This article is licensed under a Creative Commons Attribution 4.0 International License, which permits use, sharing, adaptation, distribution and reproduction in any medium or format, as long as you give appropriate credit to the original author(s) and the source, provide a link to the Creative Commons license, and indicate if changes were made. The images or other third party material in this article are included in the article's Creative Commons license, unless indicated otherwise in a credit line to the material. If material is not included in the article's Creative Commons license and your intended use is not permitted by statutory regulation or exceeds the permitted use, you will need to obtain permission directly from the copyright holder. To view a copy of this license, visit http://creativecommons.org/ licenses/by/4.0/.

(C) The Author(s) 2018 